\title{
The Role Of CSR In Achieving Sustainable Development - Theoretical Approach
}

\author{
Karoly Behringer, PhD student \\ 'Enterprise Theory and Practice' Doctoral School, \\ University of Miskolc, Hungary \\ Krisztina Szegedi, PhD, Associate Professor \\ Department of Business Enterprises, University of Miskolc, Hungary
}

doi: 10.19044/esj.2016.v12n22p10 URL:http://dx.doi.org/10.19044/esj.2016.v12n22p10

\begin{abstract}
The study is looking for the answer to the question that how the theory of Sustainable Development and that of Corporate Social Responsibility are linked, by means of what development process the two theories came near to each other and why is it that CSR is considered to be the corporate concept of Sustainable Development. The aims of this study are: (1) to give a synthesized approach to both of Sustainable Development and Corporate Social Responsibility concepts (2) to find the relationship between Sustainable Development and Corporate Social Responsibility based on the content analysis of the main milestones of Sustainable Development process, and (3) to highlight some practical relevance of the relationship of the two concepts which can be a basis of further empirical researches. Based on the research the concept of Corporate Social Responsibility and that of Sustainable Development progressed separately for a long time. The business sphere got a larger and larger role in sustainable development and it has become clear by now that CSR contributes to the sustainable development of the business sphere and without that sustainable development cannot be attained.
\end{abstract}

Keywords: Sustainable development, corporate social responsibility, corporate responsibility, business ethics

\section{Introduction}

Many misunderstandings can be experienced in relation to the concept of sustainable development, corporate social responsibility and the relationship between them. There is no consensus about their definition, but furthermore it is not always clear whether these issues are corporate issues or government issues or both of them. 
Over the past decades, sustainable development has often been compartmentalized as an environmental issue. According to an even more limited conception sustainable development is development as purely economic growth, referring to the wealth of developed countries, which jeopardizes natural resources, biodiversity and natural environments. In the last two decades it became clear that economic and environmental issues cannot be separated from social concerns, but the integration of these areas is not easy and needs a new development paradigm (Drexhage \& Murphy, 2010). Regarding the fact that who should act in favour of sustainable development, the emphasis was often shifted: while in the beginning the emphasis was clearly laid on the responsibility of the governments, in the 1990s there appeared the responsibility of civil society actors, and then since the beginning of 2000 the responsibility of the business sphere has also been emphasised (Steurer, 2013).

It is not a coincidence that regarding sustainable development the business sphere also comes up, particularly the responsibility of large companies. As a consequence of globalization multinational companies being present in several countries, the companies gained significant ascendancy. Based on the total list which was compiled on the basis of data from the World bank (2014) and the Fortune Global 500 (2015) in 2014 out of the world's 100 largest economies - countries and corporations - 42 of them were corporations. Figure 1. shows the world's 100 largest economies in 2014, countries are marked with dark colour, corporations with light colour. On the top of the list was the United States of America with 17,419 billion US dollar nominal GDP, number two was China with 10,355 billion dollars and number three was Japan with 4,601 billion dollars. 
Figure 1. The World's 100 Largest Economies in 2014 (GDP or Revenues in billion USD)

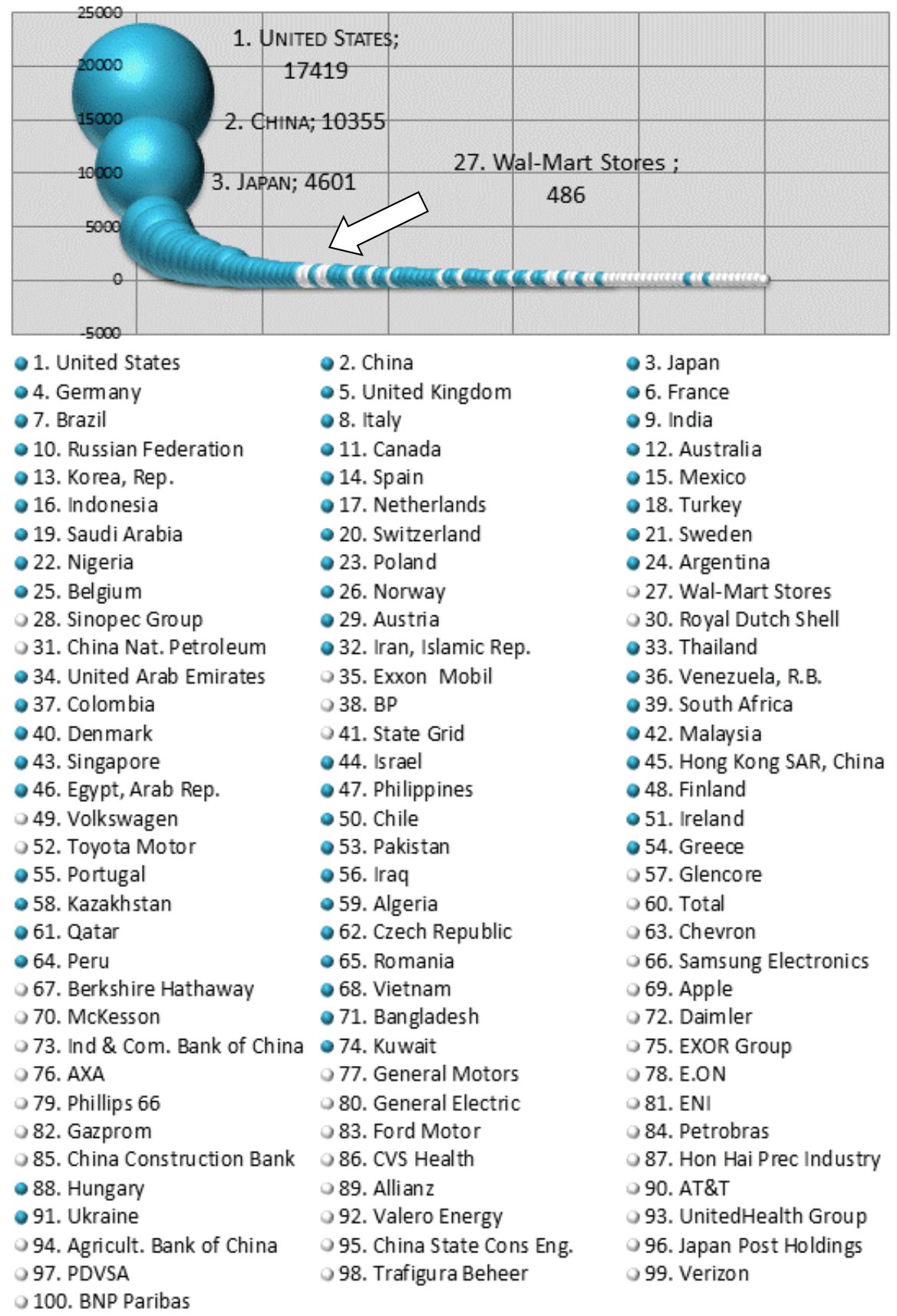

Source: Created by the authors based on The World bank, 2014 and Fortune Global 500, 2015

Wal-Mart Stores, the company with the biggest sales revenue was number 27 on the list of the largest economies. It was followed by a Chinese oil company called Sinopec group on the 28th place. In the total order of 
rank Royal Dutch Shell was number 30 followed by China National Petroleum which is also a Chinese oil company. The legal means of certain countries are not completely able to regulate the activities of large companies extending over borders thus the emphasis is shifted over the self-regulation of companies.

\section{The concept of sustainable development}

Sustainable development has several definitions. Based on them it is worth highlighting the main focuses of sustainable development which determine the essence of this term:

- Focus on meeting needs - According to the first, well known definition of sustainable development written in the so called Brundtland report, sustainable development is "development which meets the needs of the present without compromising the ability of future generations to meet their own needs." (United Nations General Assembly, 1987, p. 41). Major objective of development is the satisfaction of human needs and aspirations such as food, clothing, shelter, jobs and an improved quality of life. Regarding sustainable development basic needs of all are emphasized (United Nations General Assembly, 1987).

- Focus on ethical values - Several ethical values and ethics approaches can be discovered in the concept of sustainable development. Equity is important concerning the right to fulfilment the needs of present and future generations (United Nations, 1992, Principle 3). Also the utilitarian theory approach can be explored, according to which the best moral action is the one that maximizes utility: sustainable development should ensure better meet the needs of the majority of the people (United Nations, 1992, Principle 5). However, there are vulnerable people in special social or environmental situations with special needs, they shall be given special priority. Furthermore, requirements of international actions addressing the interests and needs of all countries refer to the equal basic rights and liberties theories (United Nations, 1992, Principle 6). Further ethical values can be found regarding multilateral trading, which should be open, equitable, secure, non-discriminatory and predictable (United Nations Sustainable Development, 1992 p. 4).

- Focus on social, economic and environmental dimensions Sustainable development includes social, economic and environmental dimensions (United Nations Sustainable Development, 1992, p 66, p 73), which should be integrated in order to achieve the goals (United Nations General Assembly, 1997, I.3) and should be balanced as interdependent pillars of sustainable development (United Nations General Assembly, 2002). The commitment to economically, socially and environmentally sustainable future was renewed (United Nations General Assembly, 2012) in 
action plan for people, planet and prosperity (United Nations General Assembly, 2015, p 1).

- Focus on human rights -Human beings are in the centre of sustainable development (United Nations, 1992, Principle 1), it is needed for human dignity for all (United Nations, 2002, p 7). The future of humanity was defined (United Nations, 2002, p 8). The importance of human rights and related laws and guidelines were reaffirmed stating that all have the right to freedom, peace, security, development, adequate standard of living, food, the rule of law, gender equality, women's empowerment, and to just, nondiscriminatory and democratic societies (United Nations General Assembly, 2012 p 2).

- Focus on cooperation -Different UN declarations refer to the importance of cooperation in order to achieve sustainability goals. States have common but different responsibilities; they have to cooperate in good faith and in a spirit of a global partnership, engaged in continuous dialogue (United Nations, 1992, Principle 10; United Nations Sustainable Development, 1992). Sustainable development requires the active participation of all major groups: women, children and youth, indigenous peoples, non-governmental organizations, local authorities, workers and trade unions, business and industry, the scientific and technological community, and farmers, as well as other stakeholders, including local communities, volunteer groups and foundations, migrants and families, as well as older persons and persons with disabilities (United Nations General Assembly, 2012, p 8).

\section{The concept of Corporate Social Responsibility}

The Corporate Social Responsibility approach has more than 50-year history and it became a global concern (Carroll \& Buchholtz, 2003) and became reality in the companies' life (Du, Swaen, Lindgreen \& Sen, 2012). However, it has not got a generally accepted definition. Similar to the sustainable development concept we highlight the main focuses of CSR (Szegedi, 2014):

- Focus on environmental and social interrelationships corporations operate in the environment and society in an integrated form. They take into account the impact their operations have on the environment and society and they want to exert a favourable effect on evolution. Some publications and corporations lay more emphasis on this component and prefer using the term Good Corporate Citizenship.

- Focus on stakeholder approach - during their operations companies make effort to take into account the interests of shareholders and further stakeholders. As all the participants concerned have an interest in the responsible behaviour of companies, the term Corporate Responsibility (CR) 
has been in use instead of Corporate Social Responsibility (CSR) recently because it reflects a broader approach.

- $\quad$ Focus on ethical behaviour - the concept of CSR does not only take into account the impact of corporate operations on the communities concerned, but it also stresses the need for ethical behaviour which respects the interests and values of these communities. Some papers consider CSR and business ethics as synonyms. Several experts think CSR is the expression of the business ethics in corporate practice.

- $\quad$ Focus on volunteering - having acknowledged their responsibilities, companies then decide to assume them on a voluntary basis. Volunteering reflects their commitments and provides them and the communities involved with opportunities to apply the most favourable instruments. Taking into account practical elements, a system giving rise to CSR or controlling does not exist. However, this does not mean that CSR cannot be motivated by government regulations or community and stakeholder expectations.

In practice, in the majority of companies CSR takes the form of charitable activities, without a profit-making goal. Typical examples are donations of money or equipment to civil organisations, participation in community events and supporting voluntary initiatives by employees. Another substantial group of companies places the goal of increasing operational effectiveness in the focus of CSR, where the point is to achieve benefits for society of the environment within an existing business model. Typical examples are sustainability initiatives that reduce consumption of resources, or reduce the amount of waste or emissions, resulting in lower costs. Other examples are investment in improving working conditions for employees, providing health care, or providing training or education; such initiatives can increase productivity and help retain employees. A few companies restructure their business models or develop new company forms (Rangan, Chase \& Karim, 2015).

\section{The relationship between Sustainable Development and Corporate Social Responsibility}

In order to find the relationship between Sustainable Development and Corporate Social Responsibility we conducted detailed content analyses of the documents of United Nations Sustainable Conferences. The studied conferences were chosen based on Sustainable Development Knowledge Platform. Figure 2 is summarising the way how business sphere appeared in the documents dealing with sustainable development. It can be seen clearly that in the beginning enterprises and large companies were only mentioned but in the 1990s crucial role is marked out for enterprises in performing sustainable development. At the end of the decade the term Corporate Responsibility appeared in the sustainability documents. In the 2000s the 
contribution to sustainable development appeared and was emphasised as a duty of corporations and as Corporate Social Responsibility and Accountability requirements. It is clear that the focus of the responsibility in achieving Sustainable Development was shifted from states responsibility toward multi-players' responsibility. The role of businesses -large corporations and small enterprises - was given special emphasis and became key point of sustainable development.

United Nations Conference on Environment and Development (UNCED), Earth Summit was organised in Rio de Janeiro in 1992 was the first milestone which aimed to strengthen the role of major groups in sustainable development.

Figure 2. Role of business in Sustainable Development milestones

- United Nations Conference on the Human Environment (Stockholm Conference)

- Focus on states' duties, only reference on responsible conduct by individuals, enterprises and communities in protecting and improving the environment in its full human dimension (United Nations, 1972, Principle 19).

- Report on the World Comission on Environment and Development - Our Common Future (Brundtland Report)

- Reference on responsibility of private enterprises, from the one-person businesses to the large multinational companies, which have more economic power than that of many countries (United Nations General Assembly, 1987, p 8).

- United Nations Conference on Environment and Development (UNCED), Earth Summit (Rio de Janeiro)

- Emphasis on the role of major groups. Business and industry, including transnational corporations, large and small enterprises play a crucial role in the sustainable development (United Nations Sustainable Development, 1992, p 289).

- Barbados Programme of Action (Barbados)

- Engagement and active participation of business and industry is required. Sustainable development activities should be supported by micro-enterprise loans at the community level (United Nations General Assembly ,1994, XV. 68, 75).

- Special Session of the General Assembly to Review and Appraise the Implementation of Agenda 21 (New York)

- Corporate responsiblity and involvement, including large corporations are important. They should promote more sustainable consumption, apply sustainable technologies (United Nations General A., 1997, II.12; III. 28 (b); IV. E (iii))).

- World Summit on Sustainable Development (WSSD), Johannesburg Summit

- Focus on collective responsibility. Both large and small companies have a duty to contribute to sustainable development. Corporate social responsibility and accountability are needed (United Nations, 2002, p 10).

- United Nations Conference on Sustainable Development, Rio+20 (Rio de Janeiro)

- The "Future We Want" requires involvement and active participation of all major groups at all

2012 levels. Importance of Corporate Social Responsibility and responsible business practices. (United Nations G. A. , 2012, p 9).

- United Nations Sustainable Development Summit 2015 (New York)

- Business sector must contribute to Sustainable Development and achivement of SD goals within the Global Partnership framework (National General Assembly, 2015, p 8, 28-29). 
Agenda 21 describes the role of large and small enterprises in details (United Nations Sustainable Development, 1992 p 289-292):

- $\quad$ Proactive companies are increasingly taking greater responsibilities due to voluntary initiatives also promote and implement self-regulations and in ensuring their activities they have minimal impacts on human health and the environment.

- $\quad$ Responsible and ethical management of products and processes from the point of view of health, safety and environmental aspects, preventive strategies, more efficient production processes, cleaner production technologies and procedures, minimizing or avoiding wastes, increasing the reuse and recycling of residues can reduce impacts on resource use and the environment.

- Due to partnerships with Governments, academia and international organizations companies should work towards the development and implementation of the sustainable development concept. Large businesses, including transnational corporations, should strive to establish partnerships with small and medium-sized enterprises to help the exchange of experience in managerial skills, market development and technological know-how.

- Companies should report annually on their environmental impacts and implementation of codes of conduct promoting the best environmental practice.

- $\quad$ The concept of sustainable development should be incorporated into the operations and investments of the companies, taking also into account its influence on suppliers and consumers.

The principles and commitments to sustainable development embodied in Agenda 21 were reaffirmed at the conference in Barbados in 1994. Specific policies, actions and measures of the major groups were required at national, regional and international levels (Sustainable Development Knowledge Platform. BPOA, 1994). A Special Session of the General Assembly to Review and Appraise the Implementation of Agenda 21 was held in New York in 1997. According to the assessment many small and large businesses have made "green business" a new operating form. One of the business related aims written in the resolution was to strengthen the interaction with major groups, through focused dialogue in order to gather information about and support sustainable development practices and the promotion of corporate responsibility and accountability of business (United Nations General Assembly, 1997).

World Summit on Sustainable Development (WSSD), Johannesburg Summit in 2002 showed an essential shift away from environment issues toward human and economic development due to the MDGs (Drexhage \& Murphy, 2010). A significant difference between the point of view of the conference held in Rio in 1992 and Johannesburg in 2002 is the increased 
presence and interest of business, which indicates the business case of sustainable development, but companies should be truly committed to sustainable development. The process has to be encouraged by governments through several tools like tax relief, environmental accounting and reporting requirements as well as by local authorities through appropriate procurement policies and by conscious customers. Greater emphasis on small- and medium-sized enterprises in areas like renewable energy and water and energy systems can create jobs and decrease poverty (United Nation, 2002, p 114, 119 and 142). The sentence "we are not asking corporations to do something different from their normal business: we are asking them to do their normal business differently" (United Nations, 2002, p 164) clearly refers to the CSR as a new business model approach. Sustainable development should be integrated into corporate strategies and programmes, including in investment and business development (United Nations, 2002, p 23).

United Nations Conference on Sustainable Development, Rio+20 acknowledged the need for further mainstream sustainable development at all levels, integrating economic, social and environmental aspects and recognizing their interlinkages, so as to achieve sustainable development in all its dimensions. It was reaffirmed to make every effort to accelerate the achievement of the internationally agreed development goals, including the Millennium Development Goals by 2015. The implementation of sustainable development needs the active engagement of both the public and the private sectors, that is why the importance of corporate social responsibility and responsible business practices, such as those promoted by the United Nations Global Compact, should be taken into account. Corporate sustainability reporting and continuous improvement of accountability and transparency should be promoted (United Nations General Assembly, 2012, p 9).

Results of the United Nations Sustainable Development Summit 2015 (New York) were published in the document transforming our world: the 2030 Agenda for Sustainable Development. It is emphasized in the first sentences of the document, that "all countries and all stakeholders, acting in collaborative partnership" should implement the sustainability plan in order to achieve the determined 17 Sustainable Development Goals (Figure 3) and 169 targets, which induce actions in the next 15 years. Within the Global Partnership for Sustainable Development framework the business sector ranging from micro-enterprises to cooperatives to multinationals must contribute to changing unsustainable consumption and production patterns with investment, innovation, job creation, compliance with international labour rights human rights, environmental and health standards (United Nations General Assembly, 2015, p 8, p 14, p 28-29). 


\section{Practical Relevance}

The conception of sustainable development has gained ground in the circle of corporations, the reason of which among others might be that the long term goals for the future are much more acceptable for the business sphere than the responsibility conception requiring immediate actions or than the critical approach of business ethics (Carroll, 2015). In fact, the economic pillar of sustainability in many cases can provide an evasion for the companies from environmental and social responsibility and also from doing the right things (Berényi, 2015). Those companies which take responsibility are heterogeneous; they have the characteristic of learning constantly where they focus on best practice examples (Bembenek, 2015).

We can experience several practical initiatives. The Partnerships for SDGs (2016) platform was created to encourage global engagement around multi-stakeholder partnerships and voluntary commitments in support of the Sustainable Development Goals. The platform contains 1941 initiatives in connection with the 17 goals.

In order to integrate business into the sustainable development Global Reporting Initiative, the UN Global Compact and World Business Council for Sustainable Development established an international network of professionals as well as perspectives of forward-thinking companies from around the world in 2015. The aim of it was to produce an implementation guide on impact assessment, KPI selection and goal setting, a publication that will support businesses in assessing their impacts, aligning their strategies with the SDGs and setting company goals (World Business Council for Sustainable Development, 2015). 
Figure 3. Sustainable Development Goals

\section{SUSTAINABLE DEVELOPMENT GOALS}

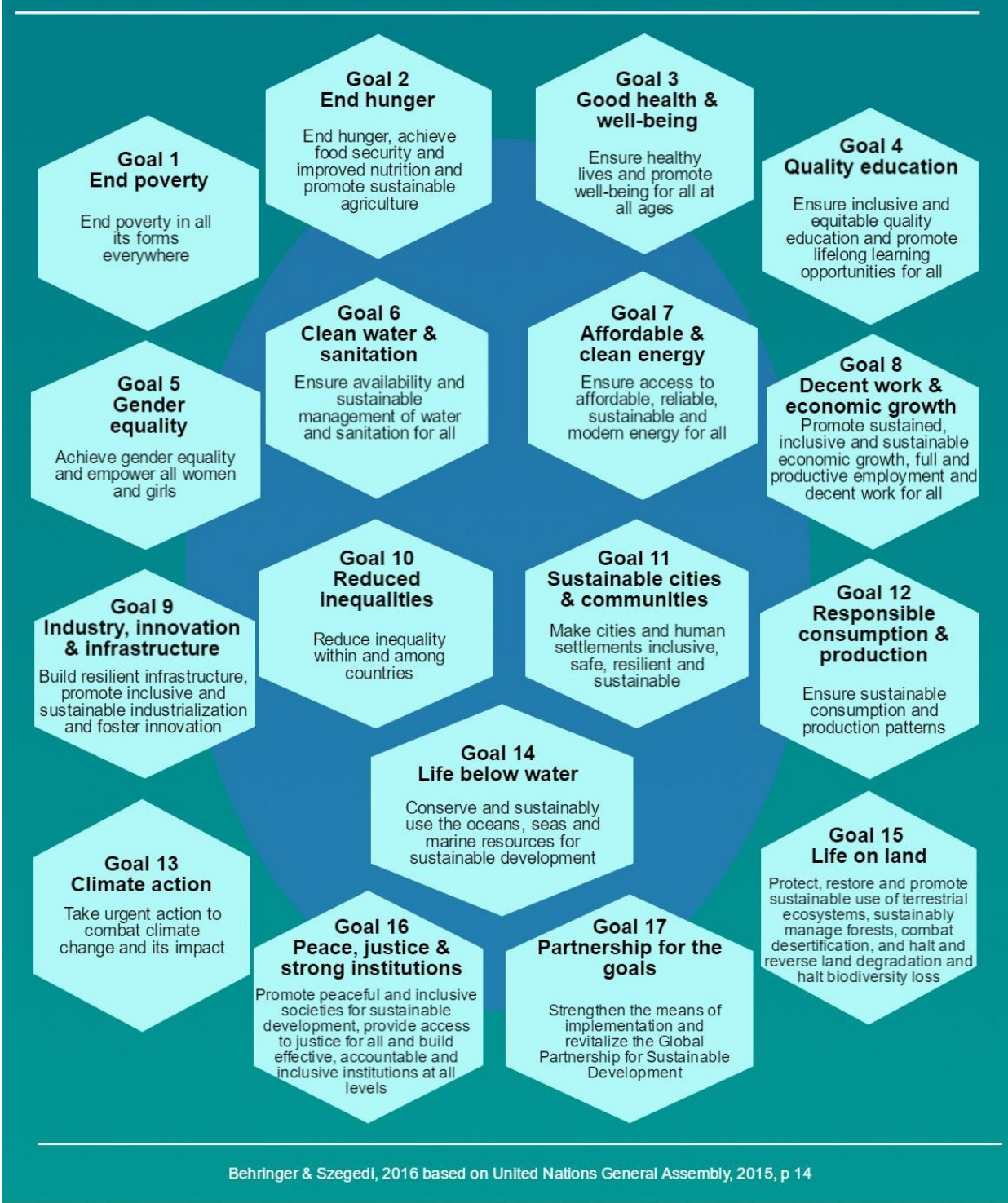

\section{Piktochart}

Source: Created by the authors based on United Nations General Assembly, 2015, p 14

The United Nations Global Compact (2016) asks companies to take business responsibly to solve societal challenges through business innovation and collaboration initiatives - both important contributions to the SDGs. Companies can join several initiatives: 
- $\quad$ Sign the Human Rights Open Letter to make human rights part of management education. More than 20 signatory businesses have with the initiative.

- Responsible Management Education - integrate internationally accepted of corporate sustainability into curricula and research. Approximately 600 signatory institutions from 80 countries have engaged with the initiative.

Global Compact Board Programme - the starting point of it that leaders have a special responsibility to corporate sustainability and to respond to the interests and concerns of all stakeholders. The initiative offers a customized facility and training program to companies.

- $\quad$ Sign the Caring for Climate Statement, a formal commitment to take practical actions. Act for the long-term in a short-term World.

- $\quad$ Pilot the Poverty Footprint Tool - The target is to implement inclusive business models and assessment tools creating a people-centred approach to look at positive and negative business impacts on the poverty.

- $\quad$ Further programs such as "Advance the Global Compact in your city", "Promote gender equality in your business", "Commit to effective climate policies", "Joining forces against corruption", "Make your voice heard on food \& agriculture", "Ask Stock Exchanges to Issue Voluntary Reporting Guidance", "Communicate the Value of Sustainability to Investors".

These initiatives indicate that it is becoming clear that companies play an essential role in achieving sustainable development goals. However, based on an international survey including 2,045 sustainability professionals only $46 \%$ of corporate SD professionals would be engaging in the new SD Goals. The most popular ones are climate change, 63 percent of the respondents deal with it, decent work and economic growth (52\%) and also sustainable consumption and production (51\%). Companies are least engaged in the following topics: reduced inequality $(28 \%)$, peace, justice and accountable institutions $(23 \%)$, life on land $(22 \%)$, end poverty $(22 \%)$, end hunger (20\%) and life below water (16\%) (Ethical Corporation, 2016).

\section{Conclusion}

The concept of Corporate Social Responsibility and that of Sustainable Development progressed separately for a long time and it was not explicit what relationship was between the two. After summarising the definitions and reviewing the development process of Sustainable Development, it can be concluded that CSR is a business model which promotes business contributions to sustainable development i.e, it creates a balance between economic interests, environmental needs and social 
expectations by integrating the spirit of Sustainable Development into the business strategy.

The interaction between the conceptions of CSR and sustainable development has strengthened in recent years; CSR is considered to be an integral part of sustainable development (World Business Council for Sustainable Development, 2000). Corporate sustainability is the company version of sustainable development, while CSR is a voluntary managerial approach to sustainable development (Steurer, Langer, Konrad, \& Martinuzzi, 2005). Corporate responsibility and corporate sustainability can be used as synonyms (United Nations Global Compact, 2013).

Governments, international organizations, the business sector and other non-State actors and individuals must contribute to changing unsustainable consumption and production patterns and move towards more sustainable patterns of consumption and production. Private business activity plays a key role to solve sustainable development challenges with its creativity, investment and innovation. A dynamic and well-functioning business sector, while protecting labour rights and environmental and health standards in accordance with relevant international standards and agreements can be an essential driving force of sustainable development (United Nations General Assembly, 2015).

The relationship between sustainable development and CSR does not remain on theoretical level but more and more practical initiatives indicate that companies have an increasing role in establishing sustainable development. Our study forms the basis of our further research, the aim of which is to examine the way how the largest companies in the world contribute to gaining sustainable development through their CSR activities.

\section{References:}

Bembenek, B. (2015). The Sustainable Development of an Industrial Cluster in the Context of Corporate Social Responsibility - A New Challenge for Cluster Management. European Scientific Journal, February 2015 /SPECIAL/ edition vol.1 ISSN: 1857 - 7881.

Berényi, L. (2015). Társadalmi felelősségvállalás a személyes vélemények oldaláról. Vezetéstudomány, XLVI. évf. 2015. 6. szám.

Carroll, A. B. (2015). Corporate social responsibility. The centerpiece of competing and complementary frameworks. Organizational Dynamics (2015) 44, 87-96.

Carroll, A.B. \& Buchholtz, A. K. (2003). Business and Society: Ethics and Stakeholder Management. 5th ed. Australia: Thomson South-Western, 2003. "Corporate Social Responsibility." Encyclopedia of Management. 2009. Encyclopedia.com. 19 Jun. $2012<$ http://www.encyclopedia.com>.

Downloaded: June 18. 2012. 
Drexhage, J. \& Murphy, D (2010). Sustainable Development: From Brundtland to Rio 2012. September 2010, United Nations Headquarters, New York.

http://www.un.org/wcm/webdav/site/climatechange/shared/gsp/docs/GSP16 Background\%20on\%20Sustainable\%20Devt.pdf Downloaded: 2015. 11.25 .

Du, S., Swaen, V., Lindgreen, A. \& Sen, S. (2012). The Roles of Leadership Styles in Corporate Social Responsibility. Journal of Business Ethics 114(1) April 2013.

Ethical Corporation (2016). State of Responsible Business 2016. London: Ethucal Corporation.

Fortune Global 500 (2015) http://fortune.com/global500/ Downloaded: 2015. 11.25 .

Partnerships for SDGs (2016). Towards full version - Jan 2016. https://sustainabledevelopment.un.org/partnerships Downloaded: 2016. 01. 25.

Rangan, V. K., Chase, L. \& Karim, S. (2015). 'The Truth About CSR'. Harvard Business Review, January-February 2015 https://hbr.org/2015/01/the-truth-about-csr Downloaded: 2016. 01. 15. Steurer, R. (2013). Disentangling governance: a synoptic view of regulation by government, business and civil society. Springer Science + Business Media New York 2013. https:/www.wiso.boku.ac.at/fileadmin/data/H03000/H73000/H73200/InFER Discussion_Papers/InFER_DP_13_3_Disentangling_governance.pdf Downloaded: 2015.11.25.

Steurer, R., Langer, M. E., Konrad, A. \& Martinuzzi, A. (2005).

Corporations, Stakeholders and Sustainable Development I: A Theoretical Exploration of Business-Society Relations. Journal of Business Ethics 61: 263-281.

Sustainable Development Knowledge Platform. BPOA (1994) - Barbados Programme of Action.

https://sustainabledevelopment.un.org/conferences/bpoa1994 Downloaded: 2016. 01. 08.

Szegedi, K. (2014). Possibilities of Corporate Social Responsibility. In: Berényi L. (Ed.) (2014): Management Challenges in the 21st Century. LAP LAMBERT Academic Publishing.

United Nations (1972). Declaration of the United Nations Conference on the Human Environment.

http://www.unep.org/Documents.Multilingual/Default.asp?DocumentID=97 \&ArticleID=1503\&l=en Downloaded: 2016. 01. 08. 
United Nations (1992). Rio Declaration on Environment and Development. http://www.unep.org/documents.multilingual/default.asp?documentid=78\&a rticleid=1163 Downloaded: 2016. 01. 08.

United Nations (2002). Report of the World Summit on Sustainable Development. Johannesburg, South Africa, 26 August- 4 September 2002. http://www.unmillenniumproject.org/documents/131302_wssd_report_reissu ed.pdf Downloaded: 2016. 01. 08.

United Nations General Assembly (1987). Report of the World Commission on Environment and Development: Our Common Future

https://sustainabledevelopment.un.org/content/documents/5987our-commonfuture.pdf Downloaded: 2016. 01. 08.

United Nations General Assembly (1994). Report of the Global Conference on the Sustainable Development of Small Island Developing States.

http://www.un.org/documents/ga/conf167/aconf167-9.htm Downloaded:

2016. 01. 08.

United Nations General Assembly (1997). Programme for the Further Implementation of Agenda 21.

http://www.un.org/documents/ga/res/spec/aress19-2.htm Downloaded: 2016. 01.08.

United Nations General Assembly (2002). Environment and sustainable development: implementation of Agenda 21 and the Programme for the Further Implementation of Agenda 21.

http://www.un.org/ga/search/view_doc.asp?symbol=A/C.2/57/L.83\&Lang=E Downloaded: 2016. 01. 08.

United Nations General Assembly (2012). The future we want. Resolution adopted by the General Assembly on 27 July 2012 http://www.un.org/ga/search/view_doc.asp?symbol=A/RES/66/288\&Lang= E Downloaded: 2016. 01. 08.

United Nations General Assembly (2015). Transforming our world: the 2030 Agenda for Sustainable Development. Resolution adopted by the General Assembly on 25 September 2015.

http://www.un.org/ga/search/view_doc.asp?symbol=A/RES/70/1\&Lang=E Downloaded: 2016. 01. 15.

United Nations Global Compact (2013). Global Corporate Sustainability Report 2013

http://www.unglobalcompact.org/docs/about_the_gc/Global_Corporate_Sust ainability_Report2013.pdf Downloaded: 2014 1 . 11.12.

United Nations Global Compact (2016). What you can do.

https://www.unglobalcompact.org/take-action/action Downloaded: 2016. 01. 25.

United Nations Sustainable Development (1992). AGENDA 21. United Nations Conference on Environment \& Development, Rio de Janerio, Brazil, 
3 to 14 June 1992.

https://sustainabledevelopment.un.org/content/documents/Agenda21.pdf Downloaded: 2016. 01. 08.

World bank (2014). Gross domestic product 2014.

http://databank.worldbank.org/data/download/GDP.pdf Downloaded: 2015. 11.25 .

World Business Council for Sustainable Development (2000). Meeting changing expectations. Corporate Social responsibility. ISBN No. 2-940240-03-5.

http://www.wbcsd.org/pages/edocument/edocumentdetails.aspx?id=82\&nose archcontextkey=true Downloaded: 2014. 11.12.

World Business Council for Sustainable Development (2015). Joining Forces for Business Action on Sustainable Development Goals.

http://www.wbcsd.org/Pages/eNews/eNewsDetails.aspx?ID=16335

Downloaded: 2016. 01. 25. 